\title{
ELEMENTAL AND MINERALOGICAL ANALYSES USING GEOCHEMICAL LOGS FROM THE CAJON PASS SCIENTIFIC DRILLHOLE, CALIFORNIA, AND THEIR PRELIMINARY COMPARISON WITH CORE ANALYSES
}

\author{
Roger N. Anderson ${ }^{1}$, Roy E. Dove ${ }^{2}$, Cristina Broglia ${ }^{1}$, Leon T. Silver ${ }^{3}$, Eric W. James ${ }^{3}$ and B.W. Chappell ${ }^{4}$
}

\begin{abstract}
Estimates of elemental and mineralogical abundances from geochemical logs are compared to preliminary chemical and modal analyses from cores in the Cajon Pass Scientific Drillhole. Accuracies of log-computed weight percent oxide and mineralogy determinations range from 10 to $30 \%$.
\end{abstract}

\section{Introduction}

The proper interpretation of the heat flow, stress, and other geophysical and geochemical experiments planned for the Cajon Pass drillhole depends critically upon an understanding of the structure, stratigraphy and lithology of the country rock. Conventional geophysical logs do not display great contrast between units that have porosities of $<2 \%$ and densities of $>$ $2.7 \mathrm{gm} / \mathrm{cm}^{3}$, as is the case of the crystalline rocks of the Cajon Pass basement. We have, therefore, made extensive use of new geochemical tools that make continuous measurements of the concentrations of major and trace elements in the well. The geochemical logs provide excellent reconnaissance analyses for quick and relatively accurate interpretation of lithostratigraphy (Anderson et al., this issue), structure (Pezard et al., this issue), and thermal conductivity (Williams et al., this issue).

The Geochemical Logging Tool (mark of Schlumberger) was developed for use in sedimentary basins by the oil industry and is now beginning to be used in igneous and metamorphic rocks during scientific drilling (e.g., in the KTB drillhole in West Germany, in the Siilgen Ring well in Sweden, and in the Ocean Drilling Program). The data quality in crystalline rocks, however, has not yet been verified.

The Geochemical Logging Tool carries three measurement devices into the borehole: a) a natural gamma ray spectral analyzer that detects the energy levels of naturally emitted gamma rays from the rock. The weight percent of $\mathrm{K}$, as well as the abundances of Th and $\mathrm{U}$ are determined by this sensor, b) a Californium neutron source/ $\mathrm{NaI}$ scintillation detector that activates Aluminum atoms in the formation, and c) a pulsed neutron, capture gamma ray spectrometer that measures the

\footnotetext{
${ }^{1}$ Borehole Research Group, Lamont-Doherty Geological Observatory and Department of Geological Sciences, Columbia University

2 Schlumberger Well Services

${ }^{3}$ Department of Geological and Planetary Sciences, California Institute of Technology

4 Bureau of Mineral Resources, Australia
}

Copyright 1988 by the American Geophysical Union.

Paper number $8 \mathrm{~L} 7340$.

0094-8276/88/008L-7340 $\$ 03.00$ abundances of $\mathrm{Si}, \mathrm{Ca}, \mathrm{Fe}, \mathrm{S}, \mathrm{K}, \mathrm{Ti}, \mathrm{H}, \mathrm{Cl}$ and $\mathrm{Gd}$. The additional use of the photoelectric capture cross-section of the formation allows for the calculation of the residual abundance of $\mathrm{Mg}+\mathrm{Na}$ (Hertzog et al., 1987).

The major element composition in dry weight percent of the oxides is estimated by assuming that in all rocks, approximately $50 \%$ is oxygen by weight (Hertzog et al., 1987). The assumptions of the distribution of oxygens are somewhat different in igneous rocks than in sediments, particularly since the Hertzog et al.'s (1987) model is carbonate-based. Therefore, we have modified the oxygen distribution coefficients from carbonate to silicate abundances.

The gamma-ray spectroscopy measurements made in the well detect a yield for each activated element that is linearly proportional to the concentration of that element in the volume of the measurement. Thus, the relative yields from each

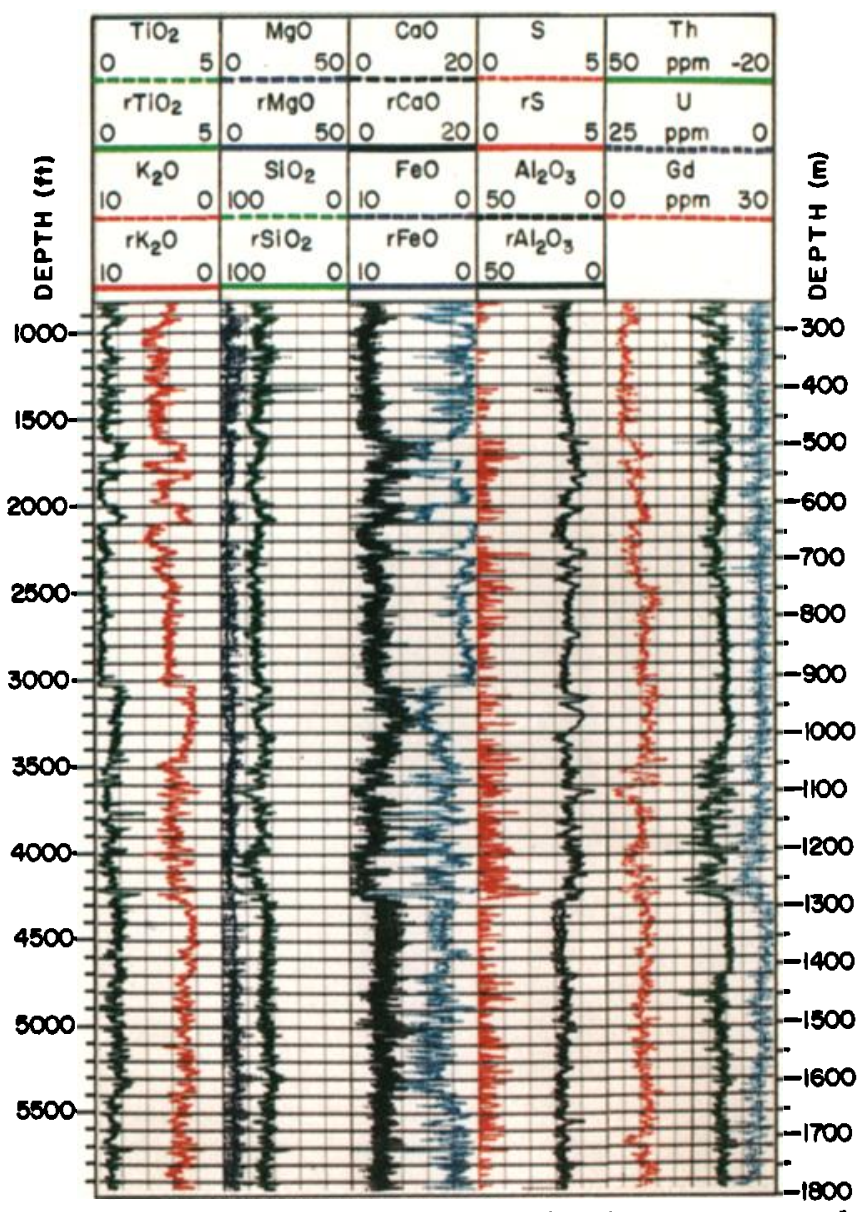

Fig. 1. Log-computed oxides of the major elements expressed in dry weight percent and trace elements (Th, $U$ and Gd, ) in ppm. Reconstructions (labeled $r$ ) of the oxides give a good measure of the goodness-of-fit of the mineralogical inversion to the original data. 
Table 1. Cajon Pass Oxide and Trace Element Analyses: Core vs. Log

\begin{tabular}{|c|c|c|c|c|c|c|c|c|}
\hline $\begin{array}{l}\text { Core \# } \\
\text { Depth (m) } \\
\text { Unit \# }\end{array}$ & & $\begin{array}{c}\text { C-5 } \\
525.5-525.7 \\
1-G D\end{array}$ & $\begin{array}{c}\text { C-10 } \\
744.4-744.9 \\
11-G R\end{array}$ & $\begin{array}{c}\text { C-15 } \\
1139.1-1140.2 \\
12-G R\end{array}$ & $\begin{array}{c}C-17 \\
1353-1353.3 \\
\text { 6-GD }\end{array}$ & $\begin{array}{c}\mathrm{C}-18 \\
1500.6-1502 \\
7-\mathrm{GD}\end{array}$ & $\begin{array}{c}\text { C-19 } \\
\text { 1655.3-1657 } \\
\text { 14-INT. }\end{array}$ & $\begin{array}{c}\text { C-20 } \\
\text { 1740-1741.4 } \\
\text { gabbro }\end{array}$ \\
\hline $\mathrm{SiO}_{2}$ & $\begin{array}{l}\text { (core) } \\
\text { (log) }\end{array}$ & $\begin{array}{c}66.4 \\
66.8 \pm 1.0\end{array}$ & $\begin{array}{c}73.3 \\
73.3 \pm 0.2\end{array}$ & $\begin{array}{c}71.1 \\
71.4 \pm 0.6\end{array}$ & $\begin{array}{c}62.9 \\
60.9 \pm 0.5\end{array}$ & $\begin{array}{c}61.1 \\
65.8 \pm 0.5\end{array}$ & $\begin{array}{c}67.2 \\
66.4 \pm 0.7\end{array}$ & $\begin{array}{c}44.7 \\
50.2 \pm 1.5\end{array}$ \\
\hline $\mathrm{TiO}_{2}$ & $\begin{array}{l}\text { (core) } \\
\text { (log) }\end{array}$ & $\begin{array}{c}0.63 \\
0.9 \pm 0.1\end{array}$ & $\begin{array}{c}0.32 \\
0.22 \pm 0.1\end{array}$ & $\begin{array}{c}0.46 \\
0.7 \pm 0.3\end{array}$ & $\begin{array}{c}0.88 \\
1.1 \pm 0.5\end{array}$ & $\begin{array}{c}1.07 \\
1.0 \pm 0.2\end{array}$ & $\begin{array}{c}0.56 \\
0.8 \pm 0.5\end{array}$ & $\begin{array}{c}1.3 \\
1.2 \pm 0.1\end{array}$ \\
\hline $\mathrm{Al}_{2} \mathrm{O}_{3}$ & $\begin{array}{l}\text { (core) } \\
\text { (log) }\end{array}$ & $\begin{array}{c}16.0 \\
12.7 \pm 1.5\end{array}$ & $\begin{array}{c}14.0 \\
15.9 \pm 0.3\end{array}$ & $\begin{array}{c}14.0 \\
13.5 \pm 0.3\end{array}$ & $\begin{array}{c}17.3 \\
20.3 \pm 2.0\end{array}$ & $\begin{array}{c}15.2 \\
15.0 \pm 0.2\end{array}$ & $\begin{array}{c}15.8 \\
16.8 \pm 0.8\end{array}$ & $\begin{array}{c}19.0 \\
18.2 \pm 0.4\end{array}$ \\
\hline $\mathrm{FeO}$ & $\begin{array}{l}\text { (core) } \\
\text { (log) }\end{array}$ & $\begin{array}{c}3.3 \\
4.1 \pm 0.5\end{array}$ & $\begin{array}{c}1.7 \\
1.4 \pm 0.1\end{array}$ & $\begin{array}{c}3.1 \\
2.6 \pm 0.1\end{array}$ & $\begin{array}{c}4.3 \\
3.6 \pm 0.1\end{array}$ & $\begin{array}{c}6.7 \\
6.0 \pm 0.2\end{array}$ & $\begin{array}{c}3.0 \\
2.6 \pm 0.1\end{array}$ & $\begin{array}{c}11.5 \\
9.3 \pm 0.6\end{array}$ \\
\hline $\mathrm{CaO}$ & $\begin{array}{l}\text { (core) } \\
\text { (log) }\end{array}$ & $\begin{array}{c}3.1 \\
6.8 \pm 1.0\end{array}$ & $\begin{array}{c}1.8 \\
3.4 \pm 0.2\end{array}$ & $\begin{array}{c}1.9 \\
1.1 \pm 0.6\end{array}$ & $\begin{array}{c}4.7 \\
5.3 \pm 0.2\end{array}$ & $\begin{array}{c}3.5 \\
4.7 \pm 0.3\end{array}$ & $\begin{array}{c}3.2 \\
4.5+0.3\end{array}$ & $\begin{array}{c}11.5 \\
9.5 \pm 0.4\end{array}$ \\
\hline $\mathrm{K}_{2} \mathrm{O}$ & $\begin{array}{l}\text { (core) } \\
\text { (log) }\end{array}$ & $\begin{array}{c}3.2 \\
3.3 \pm 0.1\end{array}$ & $\begin{array}{c}4.5 \\
3.7 \pm 0.1\end{array}$ & $\begin{array}{c}4.8 \\
4.0 \pm 0.2\end{array}$ & $\begin{array}{c}2.4 \\
2.4 \pm 0.2\end{array}$ & $\begin{array}{c}3.4 \\
3.0 \pm 0.1\end{array}$ & $\begin{array}{c}4.3 \\
3.6 \pm 0.1\end{array}$ & $\begin{array}{c}0.9 \\
1.5 \pm 0.1\end{array}$ \\
\hline $\mathrm{Na}_{2} \mathrm{O}+\mathrm{MgO}$ & $\begin{array}{l}\text { (core) } \\
(\log )\end{array}$ & $\begin{array}{c}5.1 \\
4.0 \pm 0.6\end{array}$ & $\begin{array}{c}3.9 \\
3.6 \pm 0.1\end{array}$ & $\begin{array}{c}3.6 \\
3.5 \pm 0.1\end{array}$ & $\begin{array}{c}6.0 \\
5.9 \pm 0.1\end{array}$ & $\begin{array}{c}6.8 \\
3.1 \pm 0.1\end{array}$ & $\begin{array}{c}4.9 \\
4.1 \pm 0.2\end{array}$ & $\begin{array}{c}8.9 \\
10.5 \pm 2.0\end{array}$ \\
\hline $\mathbf{U}$ & $\begin{array}{l}\text { (core) } \\
\text { (log) }\end{array}$ & $\begin{array}{c}1.91 \\
3.8 \pm 0.5\end{array}$ & $\begin{array}{c}1.01 \\
1.7 \pm 0.2\end{array}$ & - & $\begin{array}{c}1.25 \\
2.0 \pm 0.1\end{array}$ & $\begin{array}{c}1.67 \\
2.9 \pm 0.2\end{array}$ & $\begin{array}{c}3.82 \\
4.9 \pm 0.2\end{array}$ & $\begin{array}{c}0.32 \\
0.4 \pm 0.3\end{array}$ \\
\hline Th & $\begin{array}{l}\text { (core) } \\
\text { (log) }\end{array}$ & $\begin{array}{c}13.3 \\
11.0 \pm 0.2\end{array}$ & $\begin{array}{c}13.5 \\
12.0 \pm 0.1\end{array}$ & - & $\begin{array}{c}7.1 \\
7.0 \pm 0.1\end{array}$ & $\begin{array}{c}14.4 \\
14.0 \pm 0.4\end{array}$ & $\begin{array}{c}11.0 \\
13.1 \pm 0.1\end{array}$ & $\begin{array}{c}0.3 \\
2.5 \pm 1.1\end{array}$ \\
\hline
\end{tabular}

element measured through thermal neutron capture reactions are renormalized to elemental oxides which must sum to 100 $\%$ at each sampling depth interval $(0.15 \mathrm{~m})$. Since the elements measured by either capture activation or natural spectroscopy make up almost all of the significant oxides of a rock (particularly when $\mathrm{Na}$ and $\mathrm{Mg}$ are also estimated), the calculations should be reliable in any geological formation (Hertzog et al., 1987). We will test the accuracy of these calculations over the seven cored intervals for which preliminary laboratory analyses from Cajon Pass are completed.

\section{Elemental Analyses from Log versus Core}

The variations in major and trace element chemistry determined from the elemental yields measured by the geochemical log are shown in Figure 1 for the first $1,829 \mathrm{~m}$ of the Cajon Pass well. These values were calculated with no calibration or other reference to core analyses.

Laboratory core analyses are often difficult to locate relative to $l o g$ depths because of incomplete core recovery. If a $10 \mathrm{~m}$ interval is cored but only $1 \mathrm{~m}$ of rock is recovered, that core could have come from anywhere within the $10 \mathrm{~m}$ interval. Also the sampling interval of core samples is different from that of geochemical logs. The core is from a specific cylinder of rock whereas the Geochemical Logging Tool irradiates an approximately one cubic meter volume surrounding the hole
(Hertzog et al., 1987). As part of an extensive geochemical analysis program on the core from the Cajon Pass well, Silver et al., (this issue) sought to minimize these cross-correlation difficulties. Great care was taken to insure maximum recovery,
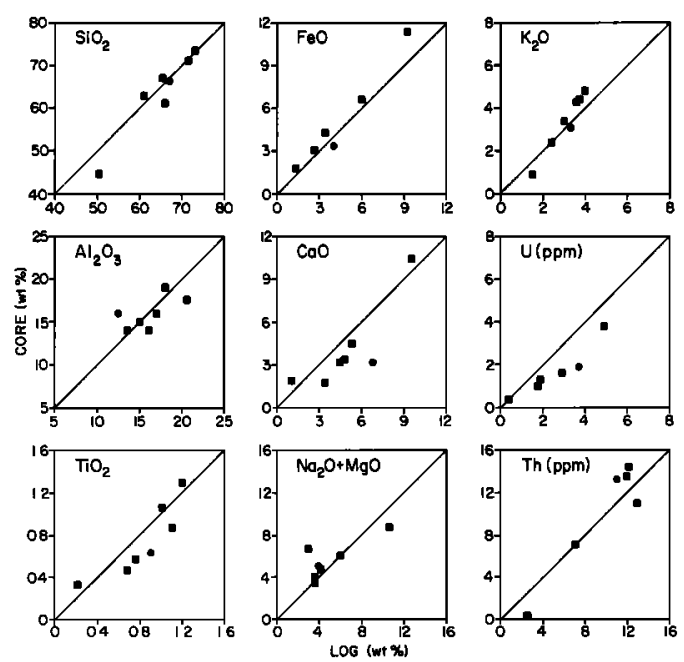

Fig. 2. Cross correlation between average log analyses and core analyses for seven intervals of Cajon Pass well (squares). Bad hole conditions make data from core C-5 less accurate (solid dots; see Table 1). 
and $>90 \%$ of each interval was indeed recovered. Also, core samples were prepared for chemical analysis in a special way to insure that the depth interval most closely represented that corresponding to the sample interval of the geochemical log. Vertical wedges were sliced from top to bottom of the entire core interval. These wedges were then powdered, thoroughly mixed, and sampled several times. The elemental analyses from core are thus averages for the interval of each core (Table 1). The log analyses were then averaged over the same interval (Table 1); the comparison is shown in Figure 2.

The geochemical logs reproduce the core analyses with

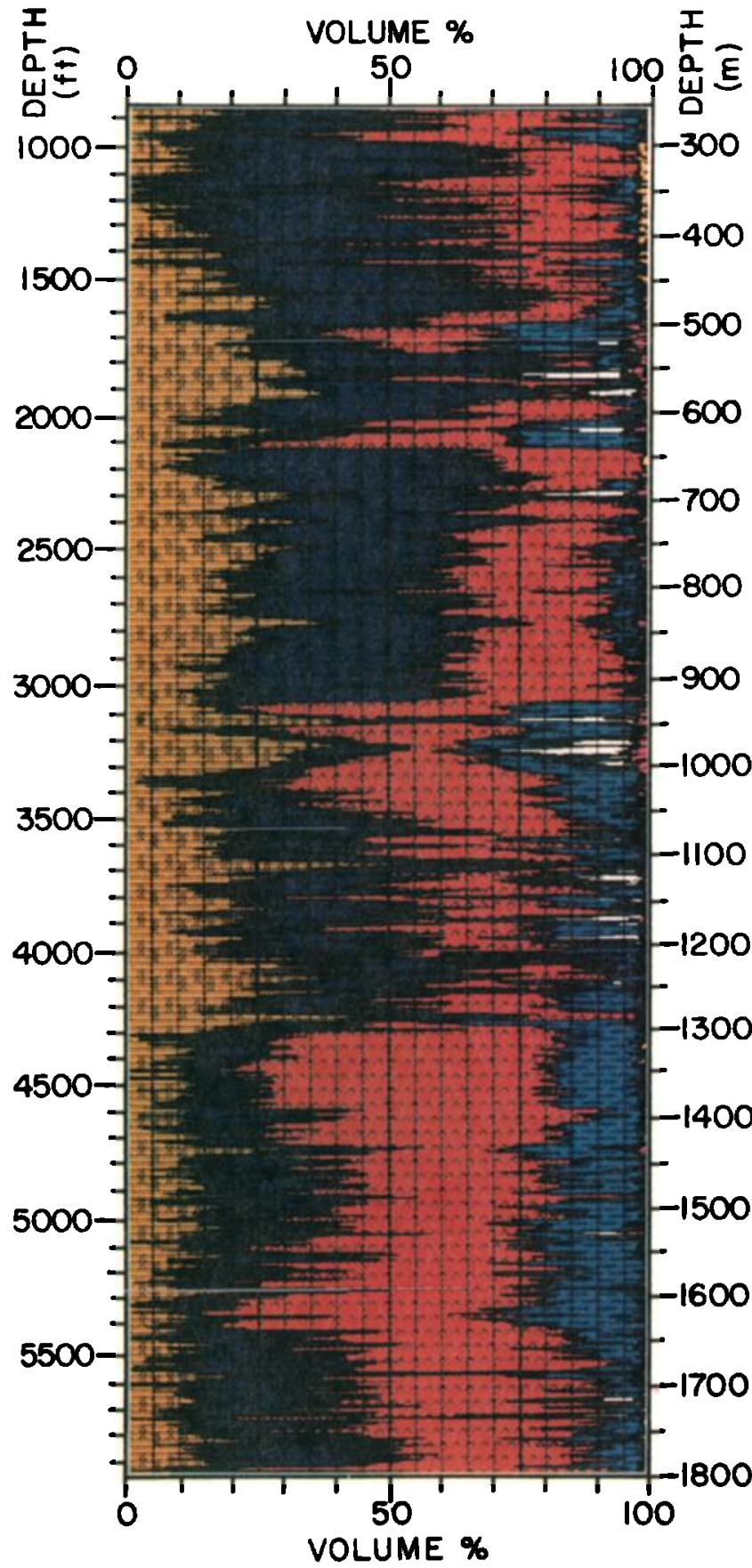

Fig. 3. Mineralogy of the Cajon Pass scientific drillhole determined from an inversion of the elemental abundances assuming ideal mineral compositions. From left to right: yellow=quartz; purple=k-feldspar; red=plagioclase; blue=biotite; white=homblende; yellow=sphene; green=pyrite.

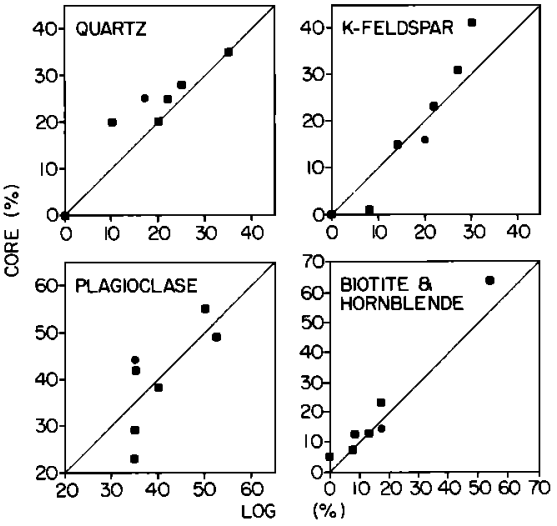

Fig. 4. Comparison between preliminary modal analyses of thin sections from seven core intervals (Table 1) and modal predictions from the mineral inversion of geochemical logging data. Squares are from the most reliable data intervals, circles represent data from bad hole intervals.

variable degrees of accuracy (Table 1). $\mathrm{SiO}_{2}, \mathrm{FeO}, \mathrm{K}_{2} \mathrm{O}$ and $\mathrm{U}$ provide the most linear of the correlations, although $U$ seems to be somewhat out of calibration (slope not 1:1). Bad hole is a significant cause of error in any logging data set, and the geochemical data appear to be affected as well. Discarding geochemical logging data from hole that is out-of-size (determined from the four arm caliper measurements: dots in Figure 2) increases the linearity of the $\mathrm{Al}_{2} \mathrm{O}_{3}$ and $\mathrm{CaO}$ correlations. $\mathrm{TiO}_{2}$ appears to be the most poorly determined major element because of its low abundance, but even this analysis is accurate to within $30 \%$. Th is reasonably accurate at concentrations greater than $5 \mathrm{ppm}$ ( $10-15 \%)$.

Though the least accurate of the major elemental correlations, $\mathrm{Na}_{2} \mathrm{O}+\mathrm{MgO}$ from the residual is within $20 \%$ of that from the core analyses, except for an inexplicable error of $50 \%$ in the analyses from core C-18 (Table 1 and Figure 2).

These seven core intervals are only the first of more than 50 that will be eventually cross-correlated with Geochemical Logging Tool results. We will await the more extensive data set before determining more accurate calibration proceedures for geochemical logging in crystalline lithologies. These data are presented in their preliminary form to verify that the geochemical logging data are indeed reliable as a reconnaissance tool for the rapid determination of geochemical variations within the Cajon Pass scientific drillhole.

\section{Mineralogy Inversion}

Elemental concentrations from the geochemical logs can be inverted using a correlation matrix to determine the volumes of ideal mineral compositions that might be present in the well (Hertzog et al., 1987). We have chosen average compositions of quartz, orthoclase, plagioclase (An 45), biotite, hornblende, pyrite, sphene, and calcite for the mineral inversion. When microprobe analyses of the elemental compositions of minerals in the Cajon Pass cores are completed, mineral inversion will be better constrained than in this preliminary study. The mineral compositions were then entered as end-members in an inversion matrix along with the weight percent oxide values of $\mathrm{Si}, \mathrm{Al}, \mathrm{Fe}, \mathrm{Ca}, \mathrm{K}, \mathrm{Ti}, \mathrm{Na}+\mathrm{Mg}$, and $\mathrm{S}$ from the geochemical 
logs. The resulting best-fit mineralogy of the well is shown in Figure 3.

Preliminary modal analyses were done on representative thin-sections from the cored intervals for which we have chemical analyses. The cross-correlation of core-derived modes and the predicted mineral volumes from the geochemical logs is shown in Figure 4. The log-derived mineralogies display somewhat lower quartz and mafic contents (perhaps $5 \%$ low) and slightly high plagioclase modes. However, we must await the full laboratory analyses of core mineral compositions before adjusting the input standards for the mineralogy inversion.

A good test of the reliability and self-consistency of the mineral inversion comes from the reconstruction of elemental compositions from the best-fit mineralogy model. Because the matrix inversion seeks the most statistically significant fit of elements to minerals, the exact reconstruction of that model-fit can show where elemental concentrations from the geochemical logs were not fitted well by the ideal mineral compositions of the model. Whereas most elemental reconstructs are indistinguishable from the input values, reconstructed $\mathrm{MgO}$ actually agrees with core analyses better than the input residual curve (Figure 1).

\section{Summary}

Preliminary evaluation of the comparison between the geochemical log-derived elemental and mineralogical abundances and core analyses shows that the log-derived chemical compositions are accurate enough to be extremely useful geological reconnaissance data in the Cajon Pass well. The elemental weight percent oxide analyses compare reasonably with core analyses; $\mathrm{K}, \mathrm{U}, \mathrm{Fe}$, and $\mathrm{Si}$ being determined most accurately. $\mathrm{Al}, \mathrm{Ca}$, Th and Ti were somewhat less well-determined, and the $\mathrm{Na}+\mathrm{Mg}$ residual is the least well-constrained of the log-derived chemical results. All appear to be accurate to within 10 to $30 \%$.

The subsequent mineralogical determination proves to be extremely useful for several of the major studies in progress at Cajon Pass. Thermal conductivity determined from the mineralogy provides a continuous description of the heat flow variation with depth when combined with thermal gradient measurements (Williams et. al., this issue). Lithologic units determined from elemental variations can be used to define the lithostratigraphy of the well (Anderson et el., this issue). Furthermore, the structural interpretation of the crystalline basement can be constrained by the mineralogical changes recorded by geochemical logs (Pezard et al., this issue).

We must wait for the full-scale interlaboratory comparison to determine the quantitative accuracy of the geochemical log data. So far, however, the results indicate that the log-derived chemical analyses are an excellent complement to geophysical logging, experimental measurements, and core analyses in studies of the Cajon Pass scientific drillhole.

Acknowledgements.We wish to thank Honor O'Malley, Colin Williams, and Philippe Pezard for helpful advice during the preparation of this paper. Elizabeth Pratson developed the silicate elemental weight percent transform. We especially thank Mark Zoback for conceiving of and carrying out the drilling of this magnificent scientific laboratory into the workings of the San Andreas Fault, and DOSECC and the National Science Foundation for supporting the effort.

\section{References}

Anderson, R. N., C. Broglia, P.Pezard, and C. Williams, Lithostratigraphy determined from discriminant analysis of geochemical well logs from the Cajon Pass Scientific Drillhole, California, Geophys. Res. Lett., this issue.

Hertzog, R., L., Colson, B. Seeman, M. O'Brien, H. Scott, D. McKeon, P. Wraight, J. Grau, D. Ellis, J. Schweitzer, and $M$. Herron, Geochemical Logging with Spectrometry Tools, Soc. Pet. Eng., paper 16792, 1987.

Pezard, P.A., R.J. Weldon, G.R. Ollier, and C. Wilkinson, A structural model for the sedimentary section within the vicinity of the Cajon Pass Scientific Drillhole, California, Geophys. Res. Lett., this issue, 1988.

Silver, L. T., E.W. James, and B.W. Chappell, Petrological and geochemical investigations at the Cajon Pass deep drillhole, Geophys. Res. Lett., this issue, 1988.

Williams, C. F., R.N. Anderson, C. Broglia, A.H. Lachenbruch, and J.H. Sass, In Situ investigation of thermal conductivity, heat production, and hydrothermal circulation in the Cajon Pass Scientific Drillhole, Califomia, Geophys. Res. Lett., this issue, 1988.

Roger N. Anderson and Cristina Broglia, Borehole Research Group, Lamont Doherty Geological Observatory, Palisades, NY 10964.

Roy Dove, Schlumberger Well Services, 365 Canal Street, New Orleans, LA 70130.

Leon T. Silver and Eric W. James, Department of Geological and Planetary Sciences, California Institute of Technology, Pasadena, CA 91125.

B.W. Chappell, Bureau of Mineral Resources, Canberra, Australia.

(Received March 11, 1988;

accepted: May 4, 1988) 